\title{
EFL Teacher Competencies in the ICT age
}

\author{
Dr: Aly A Qoura \\ Professor of ELT
}

\section{Abstract}

The present research aims at identifying key factors
which may have a significant impact on EFL
teachers' skills of ICT in the 21st Century and beyond. Teachers need to understand not only how to use technologies, but also the benefits and costs their adoption and integration into English language arts and literacy teaching. Technology integration in any content area is most effective when the instructor, an expert in his or her discipline, makes important connections between the objectives and pedagogy of his or her content area and the available technology tools. The use of computer technology, with internet can be helpful for learning, improving, practicing and assessing different skills. Technology in the classroom makes learning more fun. Technology prepares students for the future. Technology helps students learn at their own pace. Technology connects with students. Technology helps in making diagnosis and intervention. Technology increases the creativity. But there are some other challenges to technology. Technology can be a distraction. Possible disconnect of social interaction. Technology can foster more cheating in class and on assignments. Students do not have equal access to technological resources. To make technology more accessible to ELL students, there are some practical ways for the teacher to get started in the classroom: build vocabulary, use handouts, create simple assignments for beginners, extended practice time, use pair and group work, teach students to consider the source. Results of the research shows that EFL teachers should master the following competencies that ensure positive learning outcomes: Successfully aligning technologies with content and pedagogy and developing the ability to creatively use technologies to meet specific learning needs, aligning instruction with standards, particularly those standards that embody 21st century knowledge and skills, balancing direct instruction strategically with project-oriented teaching methods, using a range of assessment strategies to evaluate student performance and differentiate instruction (including but not limited to formative, portfolio-based, curriculum-embedded and summative), acting as mentors and peer coaches with fellow teachers, designing developmentally appropriate learning opportunities that apply technology- 
enhanced instructional strategies to support the diverse needs of learners, mastering basic hardware and software operations, as well as productivity applications software, a web browser, communications software, presentation software, and management applications.

\section{Introduction}

Long gone are the times when teachers used blackboards to teach young ones; how letters are shaped, words are formed and sentences are structured. These days internet provides humans with better options, the digital tools appeal to human eyes in a different manner and hence chip in the element of fun in the learning process. Where we see a dramatic increment in number of students whose first language is not English it is important we devise unique and feasible methods to facilitate English learning.

To keep abreast of the needs and abilities of the ICT age, we need to recruit, reward, train, learn from, and honor a new generation of talented teachers. The foremost importance should be given to successful teacher preparation programs because we ask much more of teachers today than even decade ago. Today teachers are asked to achieve significant academic growth for all students at the same time that they instruct students with evermore diverse needs. Teaching has never been more difficult, it has never been more important, and the desperate need for more student success has never been so urgent. Are we adequately preparing future EFL teachers to win this critical job?

The purpose of this paper is to identify key factors which may have a significant impact on EFL teachers' skills of ICT in the 21st Century and beyond. The traditional classroom has transformed itself from an auditorium with a chalkboard to a place (not even a room as education may be arranged virtually) with an access to the Internet flooded with various learning tools and resources. A lot of attention is paid to implementing ICT into educational process at all levels. However, the most important thing about ICT in education is not the governmental policy but teachers themselves, their attitude towards ICT, their knowledge and skills to work with it, their willingness to use it and readiness to further education in this domain. 
Berk (2016) notes that when it comes to technological tools facilitating learning of grammar and language skills, the few very renowned and helpful ones are: Interactive white boards, Classroom flipping many academic institutes have revolutionized using this approach. For language learning, tools like: Prezi, Screencast-o-Matic, Voice Thread, Captivate, PowerPoint, Camtasia, and YouTube fall under the category of flipped learning. , Social media tools Twitter for instance caters few very helpful learning platforms such as: Cambridge Words, English247, BBCle, EnglishTips4U, Learn English_BC. Apart from this Instagram has boomed with a novel concept of learning through visual aids and Pinterest also follows the pied piper lead. Many instructors also consider creating a Facebook page that their pupils can like. They post updates in different languages encouraging non-native speakers to translate them. Moreover blogging on Tumblr may also be used as an inspirational technique that motivates learners to submit their precise views and ideas in English.

There is a list of apps offered by IOS such as: Nearpod, Coursmos, Notability, Plan Book Touch, Ever note. All of them are some amazing mini digital forums that help non-native speakers learn English without facing problems. These foster improved communication skills, help them get better jobs, give lessons confidently, and above all get good grades. For android the best options are: Busuu, Fluent English, Listen \& Speak, and English Podcast for Learners.

The introduction and development of the Internet, by and large, have had considerable implications for foreign or second language instruction. Numerous resources on the World Wide Web (WWW) offer language teachers convenience and support in language teaching and learning, (i.e., English as a foreign language (EFL) and English as a second language (ESL) instruction).

It is no wonder that more and more language teachers have integrated the Internet into the classroom during the last 10 years. This fact has brought revolutionary reform to language 
teaching methodology in the sense that both teacher and technology roles play equally important roles in creating innovative language learning classrooms. Currently, in many EFL/ESL contexts, the integration.

\section{Beliefs about Technology and the Preparation of English Teachers:}

Teachers, individually and collectively, have of Internet technology into the classroom, for example, is seen as a central issue owing to pursuing interactive teaching practices (Parks et al, 2003; Yang, 2001). Consequently, many EFL teachers, for instance, are concerned about the efficient application of the Internet to help students engage in a meaningful and interactive learning environment (Koehler, Mishra, Hershey, \& Peruski, 2004).

The capacity and the responsibility to influence the development, modification, adoption, and/or rejection of newer technologies. In order to make these critical decisions, they will need to understand not only how to use these technologies, but also the benefits and costs their adoption and integration into English language arts and literacy teaching have the potential to create for teachers, students, and the broader community. Since best practice in teaching requires that it be specific to individual students, classrooms, and communities, such decision-making will require additional research on the classroom as well as national levels. However, Feenberg (2003) and Yagelski (2005), among others, have warned educators not to conflate the adoption of newer technologies with progress. In other words, both men caution us not to view the integration of newer technologies into English language arts and literacy teaching as scaffolding innately and universally desirable outcomes-or as determinist.

A number of beliefs and/or foci have been presented by Young (2016) in a position paper. These belief statements are an attempt to suggest the possible changes that consideration of suchtechnologies might stimulate. Salient among these changes are: 
- There is no consensus on what we are talking about when we talk about integrating "technology" into teacher preparation.

This means on teaching new technologies rather than English language arts/literacy learning is short-sighted since many newer technologies have relatively short lifespans. On the other hand, many new literacies and modes of inquiry require direct instruction on the use of hardware, peripherals, software, and interfaces.

- Digital technologies change print-based concepts of text, reader and require new literacy strategies.

Digital texts both imitate and expand existing print forms. Some digital texts share common forms and common purposes: the online newspaper, for example, is similar in many ways to its print-based counterpart. At the same time, digital texts possess characteristics that are unique to the digital medium, challenging our ideas about what texts are and how they work. More specifically, digital texts may be hyper textual and multimodal, linking to a multitude of other texts; they are dynamic, changing content in real time. Also, they are indeterminate, with no definite beginning or end, and multimodal, incorporating visual, auditory, and other non-verbal elements. New digital genres, such as web pages, web logs, multi-user virtual environments like MOOs and MUDs, and collaborative writing platforms like wikis and threaded discussions are evolving and new digital grammars emerge with each new form.

Technology integration in any content area is most effective when the instructor, an expert in his or her discipline, makes important connections between the objectives and pedagogy of his or her content area and the available technology tools.

Implications here start with the fact that a careful consideration and analysis of composing processes and products that include multimodal literacies and multimedia technology will better inform our learning, teaching, and ways of thinking 
about composition, composing processes, and conceptions of an expanded, multimodal notion of text and meaning-making.

- The composing process yields a variety of legitimate and effective products, outcomes, and artifacts that go beyond the printed page, including hypertext, hypermedia, web design, digital literacy portfolios, PowerPoint presentations, and digital video documents.

- Using multimodal literacies and multimedia technologies for example, has the potential to make the composing process and the subsequent texts produced more dynamic, interactive, generative, exploratory, visual, and collaborative.

Technology should not replace the writing teacher; however, teachers will need to embrace new and emerging technologies with respect to teaching composition and coaching students' development of effective writing processes and products.

\section{Al Sied and Al Pathan (2013) showed how technology can help teach the four language skills:}

The use of computer as a listening tool is claimed to be one of the more important learning tools for enhancing EFL students' listening skill. It allows students to learn independently and to receive immediate feedback upon the completion of tasks. Teaching and learning of listening using various media embedded in computer can enrich the skill and help in producing better results. The use of computer also gives students the opportunity to enhance language learning by bringing in the real world. Digitized speech and video, offered by the use of computer, can also be highly effective for developing this important language skill.

The use of computer technology, with internet, can also be helpful for learning, improving, practicing and assessing speaking skill. EFL learners can use computer, tablets and Smartphones, connecting with internet, to chat and talk with native speakers and practice and improve their language, in 
friendlier foreign language learning environment. Today many social networking sites like Skype, Nimbuzz, Yahoo and Facebook etc. allow this kind of audio as well video talk, in addition to IM (instant messaging) service. This kind of online talk, with native speakers of English, has been advocated, as very useful tool for improving speaking proficiency as well as pronunciation by the scholars like Payne and Whitney (2002) and (Al Sied and Al Pathan, 2013) assure that such use of computer technology also gets even the reluctant EFL learners to speak. Thus, the use of computer technology for developing speaking provides learning opportunities where there are less teacher fronting and are authentic and challenging situations for improving this important skill.

In addition, using computers, with the use of internet provides a variety of current and authentic reading materials compared to potentially out-dated reading material sourced from textbooks (Kasper, 2000). Chun and Plass (1997) stress that the verbal and visual systems in computer programs help students to better understand the text. Most of the CALL programs are filled with graphics and voices and when EFL learners visualize the situation, they can remember the subject better in the long term.

The varieties of reading materials, available with the use of computer technology and internet can encourage EFL learners and open opportunities to read widely in foreign language like English. That is why it is argued that computers can promote extensive reading; build reading fluency and rate; develop intrinsic motivation for reading; and contribute to a coherent curriculum for student learning.

Cunningham (2000) concluded that his students found that his writing class was more productive when he used word processing software with his students. He surveyed 37 EFL students in his writing class to study the students' attitudes towards using computers in their writing. $88 \%$ of students indicated that they had improved their writing skills whilst using word processing. These students indicated that using a word 
processor during the writing process helped them to concentrate on certain aspects of their writing, for example: grammar, vocabulary and the organization or structure of their text. Similar results were also reported by Kasper (2000) which highlight the useful role of the use of computer technology in developing writing skill of EFL learners.

Finally, the use of computer, to assess and test EFL learners, ensures correct assessment of their language ability. Many scholars like Chapelle, and Douglas (2006); Dandonoli (1989); and Stansfield (1990) etc. have advocated this use of computer technology in the field of foreign language assessment and testing. There are many useful websites which provide language learners with many online tests. English as foreign language learners can visit them and assess their language ability and proficiency. Some of these websites include: www. dialang. org, www.market-leader.net, www.ecollege.com, www. myenglishlab. com, www. Hotpot. uvic. ca, www.school.discovery.com etc., to mention a very few. In addition, EFL teachers can prepare their own online tests, for their students, for the courses being taught by them through using authoring programs like Hot Potatoes, Macromedia Author ware etc.

\section{Advantages and Challenges of Integrating Technology in the EFL/ESL Classroom:}

In a number of ways technology enhances both the teaching and learning of the English language, increases students' motivation, and positive attitude towards learning the language. However, the introduction of technology in schools has faced challenges and great deal of resistance.

To start with the advantages and as we sail through the $21^{\text {st }}$ century, technology in the classroom is becoming more and more predominant. Tablets are replacing our textbooks, and we can research just about anything that we want to on our smartphones. Social media has become commonplace, and the way we use technology has completely transformed the way we live or lives. 
The impact that technology has had on today's schools has been quite significant. This widespread adoption of technology has completely changed how teachers teach and students learn. Teachers are learning how to teach with emerging technologies (tablets, iPads, Smart Boards, digital cameras, computers), while students are using advanced technology to shape how they learn. By embracing and integrating technology in the classroom, we are setting our students up for a successful life outside of school. Here are a few benefits of using it.

\section{Technology in the Classroom Makes Learning More Fun:}

Students prefer technology because they believe that it makes learning more interesting and fun. They especially like laptops and tablets. Subjects that students deem challenging or boring can become more interesting with virtual lessons, through a video, or when using a tablet.

\section{Technology Prepares Students for the Future:}

A study by Becta (2006) showed that 9 out of 10 students indicated that using technology in the classroom would help prepare them for the digital future. These 21st-century skills are essential in order to be successful in this day and age. Jobs that may not have had a digital component in the past may have one now. Education isn't just about memorizing facts and vocabulary words; it's about solving complex problems and being to collaborate with others in the workforce. Ed-tech in the classroom prepares students for their future and sets them up for this increasing digital economy. This can be done by the many opportunities for language practice it provides. Students can play with language and the context and it is more informal. They can get involved in the writing process by posting blog entries, editing to other pages, creating their own e-portfolios.

\section{Technology Helps Students Learn at Their Own Pace:}

Today's technology enables students to learn at their own pace. For example, almost all apps allow for individualized instruction. Students can learn according to their abilities and needs. This form of teaching is also great for the teacher because 
it gives him/her the time to work individually with students who may be struggling. .This kind of flexibility made Lessons easier to adapt with some of the online programs available to teachers. This aspect may help facilitate student conceptual understanding as well as student engagement and motivation. With electronic resources, teachers could easily give students different assignments and assessments designed specifically around each student's growth targets. Some of the technologies, incidentally, helped alleviate problems with cheating and/or not doing the work, although not all resources had built-in safeguards against cheating. It allows users to become the producers of the knowledge. Using Web 2.0 or later versions enable us to share our work with other audience. For example, E-pals project is considered to be the world's largest online classroom.

\section{Technology Connects with Students:}

Technology occupies an important place within students' lives. When they are not in school, just about everything that they do is connected in some way to technology. By integrating technology into the classroom, teachers are changing the way they used to teach (lectures six hours a day) and providing students with the tools that will take them into the 21st century. When they are in school technology ensures collaboration. These technologies offer structures and support for student-student and teacher-teacher collaboration. It engages students. In fact, technology is always engaging. When we use these tools in classes, it doesn't seem like a required assignment for students. It also helps us to motivate our shy students to participate more in our lessons and the willingness to create and share is a great opportunity to learn and participate. It shifts the classroom experience from the sage-on-a-stage approach to a more collaborative environment. Imagine that your student raises her hand and says, "I know exactly what you mean! I saw a similar case on YouTube last week. May I share it with the class?" Student rushes to the lectern, finds it on Youtube, and everyone (including you!) learns something new. Researching on the spot becomes easier. 
Furthermore, these opportunities are not limited to one classroom or one lesson, but can span time and distance. In addition, technology offers many variations on the same lesson. When students do not "get" a concept, rather than repeating the same thing slower and louder, technology allows for presenting it differently. Using Web 2.0 for instance can easily create social networks and communities of interest. I believe Wikipedia and Ning are the best examples for this and they are all free.

\section{Technology helps in making diagnosis and intervention:}

When student work is done online, teachers are able to receive immediate results and students to get prompt feedback. This immediacy enhances both the grading process and student learning. Teachers quickly address student misconceptions, lack of content background, or need for practice. These advantages mean that students can take the next steps in their learning without waiting for the teacher to grade stacks of papers or for large-scale class assessments to be completed. Overall these technologies, by their nature, offer the teachers opportunity to teach in a student-centered fashion. Fewer lessons are "controlled" by the teacher's plan alone; rather they are led by the natural direction the students took as they encounter the online materials.

\section{Technology increases the creativity:}

Any student can write film and publish a video or an audio. YouTube and Google video are used by our students every day. They watch more videos on YouTube than they watch on T.V. or cinemas.

\section{Challenges facing the technology integration in the EFL/ESL classrooms}

Peachy (2015) contends that computers are meant to have transformed the way language is taught and learned but in many classrooms expensive equipment is of little value and barriers to successful integration remain open to question. We are now 16 years into the new millennium and technology has become a prime element of almost all English language teaching (ELT) 
conferences and journals around the world. Yet, when we look for real improvements in student performance and effective use of technology by teachers, I think that the results are pretty disappointing.

Investment in technology has often been equated with investment in hardware. In many ways this is the easy fix: throw money at the challenges that technology integration poses. For example, education ministries around the world have been willing to invest in expensive interactive whiteboard (IWB) technology without really considering the benefits inside classrooms. Having made the investment, teachers are often left to sort out how to use IWBs in a pedagogically effective way, often with very little training or support. Meanwhile managers can wash their hands of the problem and report back that they have done their part in integrating technology. That is why much resistance and cynicism exists among teachers to the introduction of technology.

Without sufficient connectivity the investment in hardware is wasted because, as soon as teachers and students start accessing content-rich websites in any numbers, the connection grinds to a halt, leaving the teacher embarrassed and reverting to traditional paper-based resources. There is also the problem of the IT gatekeeper. Nik (2015) made the point that very few IT support staff has any pedagogical training and they tend to see themselves as defenders of the IT infrastructure. So, rather than being a friendly doorman who invites teachers in and helps them realize their technological aspirations, they can be defensive and hostile. Often this is exacerbated by a breakdown in communication because both sides lack a common vocabulary for explaining problems.

Many schools have made the effort to try to put technology into the hands of students by creating computer rooms, but in most of the schools these tend to be fixed, desktop computers built into rows of tables. These computers rarely have any of the peripheral devices such as microphones, headphones or webcams that would transform them into tools for communication and oral skills development. 
The design of the desktop computer and the upright screen often mean that once students are on the computers and logged in it's very difficult to get their attention away from the screen. It is almost impossible to start moving students around the class for more social interaction. Also, the fact that these are separate classrooms that teachers need to book out and take their students to for a specific time slot adds yet another obstruction.

It is noticed in many schools that the focus of much training is still on hardware and "office" applications or ELT specific software. Training for equipment such as IWBs often comes after the equipment has been introduced into the classroom and although there is some useful software for language learning, it is often simply a digitized version of standard course book content dominated by gap-fill and matching activities.

Mantano (2015) pointed out some other challenges and proposed how to cope with:

\section{Technology can be a distraction:}

This makes the notion of creating a structure and culture of respect all the more important since day one. Identify specific projects, times during class, and the specific intentions you have for allowing the use of technology in the classroom. Creating expectations and guidelines for the students, and sticking to them, will be important for them in respecting your boundaries. It will be better to use technology that students already have (smartphones, laptops, etc.) for good and valuable learning experiences, rather than pretend like those devices aren't present in your class in the first place.

\section{Possible disconnect of social interaction:}

This can happen, but it doesn't have to. Many people are skeptical of technology and what it does to students' (and everyone else's) ability to verbally communicate. If you create assignments in class that use both technological tools as well as oral presentations and collaboration, this will teach students to be dynamic in how they learn and interact with others. 


\section{Technology can foster more cheating in class and on assignments:}

However, this will only happen if you give up hope on adjusting your students' attitudes and only give them subjective assignments that require no thought or perspective.

\section{Students do not have equal access to technological resources:}

There will be students who do not have iPads or cameras or even the textbooks for class. It will be up to you to point them in the direction of the library or community resources, or to create assignments that allow them to work in groups and share resources. That being said, close to $95 \%$ students have some sort of technology devices, even if it's just a cell phone.

The quality of research and sources they find may not be top-notch. The internet is both a blessing and a curse. Your students may need some guidance on identifying proper sources and unreliable sources. Many campuses have writing centers that can help with this.

Lesson planning can become more labor intensive with technology. Yes, for some. It can seem overwhelming to adapt technology into your classroom. In many ways though, using technology can become as natural to you as any daily activity. Allow yourself time to learn how to use something. Chances are your students will learn it even faster than you since they've grown up surrounded by technology.

Barnawi (2015) examined EFL teachers' beliefs, attitudes, willingness, and concerns towards Internet-based EFL instruction. The findings his study indicated that most of the participants showed positive attitudes and willingness to integrate the Internet into the classroom and viewed the Internet as a wonderful and rich source of information for teachinglearning purposes. However, factors such as a lack of training on the use of the Internet, a lack of technology resources, cultural appropriation, and imposition of traditional methods of instructional delivery could be possible internal and external impediments to the use of the Internet in the classroom. 
There is no doubt that having (or not having) excellent technological skills will make a major difference in the lives and futures of our students. Their careers will increasingly rely on the ability to maneuver easily in technological environments, and to learn new technology quickly. Yet there are a number of challenges that educators face when trying to help ELLs get up to speed (Robertson, 2016):

- Language: In order to make the most of instructional technology, ELLs need to have the language skills and vocabulary necessary to understand how to use the technology.

- Limited access: Many ELLs may not have access to a computer or the Internet in their home. They also may not know about the services available through the school or library, or they may be unable to get to the library on a regular basis.

- Different levels of experience: In one classroom, a teacher may have a student who learned to use the computer as a toddler, and another who is sitting in front of a computer for the first time. This requires that teachers develop their own ability to differentiate technology instruction for their students.

- School infrastructure: While many schools around the country have invested heavily in technical infrastructure and equipment, many have not - including numerous schools serving ELLs.

- Keeping up: It's hard for teachers to keep up with new jargon, information overload, and the latest technical tools and trends - not to mention the ways these things all relate to the classroom!

The question we need to look at is: How do we make technology more accessible to ELL students? Here are some practical ways to get started in your classroom.

\section{Build vocabulary:}

There are so many words specific to technology, and since they have become increasingly common in daily use, it is easy to 
overlook the basics. For example, an ELL student may know that a mouse is an animal, but may not know that "mouse" also refers to the tool we use to move a computer's cursor. Here are some tips for teaching technical vocabulary:

- Find out what students know: Put students into small groups and give them a list of new words. (This may be an appropriate time to put students into groups with peers who speak the same native language.) Ask them to talk about which words they know, and to write down multiple meanings so that you can help clarify appropriate usage. After students have had a chance to discuss the list, ask the groups to share their ideas with the whole group.

- Review the basics: Offer a very basic introduction to technological vocabulary words that students are likely to encounter, including parts of the computer (mouse and screen), items that students may see on their screen (cursor and menu), and verbs referring to what they will be doing when they use the computer (click, double-click, scroll, cut, paste, highlight, etc.)

- Use props and demonstrations: For ELL students, be sure to demonstrate the meaning of the vocabulary word with a visual prop or an action.

- Check comprehension: Ask students to demonstrate the meaning of new words for you as well so you know they understand. You can also have them quiz each other in pairs, and write definitions in their own language or use drawings to demonstrate comprehension.

\section{Use handouts:}

One of the difficulties students face in any technology course is the challenge of trying to follow along on their own computers while the teacher demonstrates the steps on a computer screen projected in the front of the class. If a student falls behind he/she may get lost and must ask for more assistance to get "caught up." 
Try giving ELLs handouts with visuals of the computer screen so that they can follow along. Many school technology departments may have these available. A basic lesson plan is offered at Eduplace entitled "Getting to Know Your Computer" if you are looking for a good place to start!

\section{Create simple assignments for beginners:}

When learning a new skill, it is best to work with known information. For example, students learning how to use the Word program to create documents should write about something with which they are familiar, rather than having to research a new topic while learning how to use the program. This may be a description of their family or school, or perhaps a summary of a story they've read.

By using "easily understood" material, the students are able to more effectively concentrate on applying their new technology skills. Once students have some proficiency in the technology, they can be challenged by creating documents with newly learned information.

- Extended practice time. If you have taught technology units to mainstream students and have an estimated amount of time for each unit, you will probably need to find ways to extend the practice time for ELLs. There are many basic skills that mainstream students start with that may take some ELL students more time to master, such as: Guiding the mouse, Clicking, Double-clicking, Dragging, Scrolling, and Using a search engine.

In addition, ELL students are making meaning of the instructions given in a second language, while also figuring out how to use the technology. If there is not more class time available, an after-school technology class with tutoring may be helpful.

\section{Use pair and group work:}

Learning is reinforced when we use it to socially construct knowledge. If students are exposed to new information, vocabulary, and technology all at the same time, they will learn 
some of it and forget some of it. If students use the new information, vocabulary, and technology to build something together or to solve a problem, they will learn it and remember it as they discuss different approaches to a problem, activate their knowledge, and learn from each other.

For example, if a group of students has typed information for a brochure and now wants to move one paragraph to another area, one student may suggest they delete the paragraph and type it in the new space. Another student may suggest that it would be better to "cut" the paragraph and "move" it to the new area. By working together the students are learning from each other and making decisions as a group that will lead to a higher quality product. This type of interactive learning also helps ELLs develop their English language skills.

\section{Teach students to consider the source:}

We receive a tremendous amount of information to process, and it leads many people to just accept the information they are provided with because they don't have a lot of time to "check it out." ELL students may be particularly susceptible to believing information they receive electronically because they may come from a culture where very little information is printed, and so written information is usually considered reliable.

Talk to your librarian or school technology specialist to see if they have orientation sessions about search engines and popular research sites, how to best conduct a search, and how to evaluate information once they find it. The Read Write Think website also offers a lesson plan entitled Research Building Blocks: Examining Electronic Sources that may provide some valuable ideas.

\section{Language and Technology: Teaching and Learning for the Future}

Just as the name suggests "language and technology" refers to all those ways individuals are taught language skills using technological advancements. May the students be ELL (English language learners) with a limited English proficiency, or simply 
foreign individuals planning for TESOL (teaching English to speakers of other languages) or TEFL, the core need remains the same: opt for the best language practices!

When it comes to technological tools facilitating learning of grammar and language skills, the few very renowned, responding to the users input. It is the most effective tool that can be used in classrooms. It records bits of information that the teacher presented during lectures which can be later reviewed by students. A teacher may jot down key pointers related to the learning program or subject matter which students may later retrieve for better assistance.

\section{Classroom flipping}

Another great idea that introduces learning in a pretty fashionable manner is classroom flipping. Where classrooms have become hubs of personalized attention from teachers, homes have become centers of online learning. Many academic institutes have revolutionized using this approach. For language learning, tools like: Prezi, Screencast-o-Matic, Voice Thread, Captivate, PowerPoint, Camtasia, and YouTube fall under the category of flipped learning. They provide individuals the opportunity to freely curate and communicate content in form of videos, slides and images.

\section{Social media tools}

Must have heard of social media language learning (SMLL)? This is the best part, where technology creeps in the communication network of students and teachers enhancing it tremendously. Twitter for instance caters few very helpful learning platforms such as: Cambridge Words, English247, BBCle, EnglishTips4U and Learn English_BC.

Apart from this INSTAGRAM has boomed with a novel concept of learning through visual aids and PINTEREST also follows the pied piper lead. Many instructors also consider creating a FACEBOOK page that their pupils can 'like'. They post updates in different languages encouraging non-native speakers to translate them. Moreover blogging on TUMBLR may also be 
used as an inspirational technique that motivates learners to submit their precise views and ideas in English.

\section{Applications and technologies}

Since the advent of remarkable OS like android and iOS, new applications pop up every other second of the day. There is a list of apps offered by IOS such as: Near pod, Coursmos, Notability, Plan Book Touch, Ever note. All of them are some amazing mini digital forums that help non-native speakers learn English without facing problems. These foster improved communication skills, help them get better jobs, give lessons confidently, and above all get good grades. For android the best options are: Busuu, Fluent English, Listen \& Speak, and English Podcast for Learners.

The teaching styles are changing and therefore learning methods need a metamorphosis too, the final word is that Technology aims at preparing the most delicious bowl of noodles for hungry English language learners.

Technology is changing how future of the Teaching of English to the Speakers of Other Languages (TESOL). With the growing demand for TESOL teachers in public schools, adult education programs and cities with large immigrant and refugee communities, TESOL teachers must now consider the "digital literacy" of their students as well as their English literacy. The first step for anyone interested in TESOL is to gain certification, which might be through an online university TESOL program.

\section{Online Tools for TESOL}

While most TESOL programs have a traditional in-theclassroom structure, many more are now available as online programs allowing students from around the world to connect via the Internet, audio tools, voice tools, Second Life (a virtual world), Skype and e-readers.

A recent development in the online learning world is a voice recording program, which allows students and professors to post audio clips on message boards making the interaction feel more "real." This technology provides students with the option to 
listen rather than read posted messages, and for audio learners this could be a significant benefit.

Some professors have also creatively used Second Life as part of their instruction. Rather than hoping the students interact with one another in their free time, the professors encourage them to visit Second Life, find areas where language learning is happening in the virtual world, and observe.

TESOL teachers are taking the technology they used in their academic programs to teach their students because they now understand technology can both assist and enhance language learning. They are using technology like Skype to connect their classroom in classrooms in other countries where students want to learn English. Other tools are used to adapt classroom activities and homework assignments so that they are targeted to the language learning level of an individual student.

\section{Digital Literacy Issues}

However, these technological advancements bring new issues. TESOL teachers must consider if their students have the digital literacy to use these tools.

If part of the instruction is to write journal entries on a personal blog, do they know how to set up a blog and then post their writings? If Skyping with another classroom is part of a weekly assignment, do they know what Skype is and how to use it? Some students will have no difficultly using technology but might need instruction on how to best write for their blog or what they should and should not post on Facebook.

As new technologies continue to evolve, teachers should also consider the impact and benefits for students before immediately adapting them into the curriculum. Do they advance what you are trying to teach or are they just a distraction? It's also important to remember that no technology is neutral. If you are integrating technology and social media platforms into your students' writing assignments, the way a platform is structured and whether anonymity is possible will impact their interaction with it. So, make sure the technology works for your students before implementing it into their learning experience. 
To assist in the debate, the TESOL International Association has developed "Technology Standards," which focus on how English language teachers, teacher educators, and administrators can and should use technology in and out of the classroom. Whether a student is learning through technology or in a traditional classroom setting, the instruction should be standards-based and help develop a student's proficiency in the target language through interactive, meaningful, and cognitively engaging learning experiences, facilitated by a qualified language teacher.

\section{Case Study: The Open University of Catalonia}

Back in 2008 The Economist Intelligence Unit in New York provided a Case Study the Open University of Catalonia that shows how technology will shape the future of higher education. In existence for 14 years, with 45,000 students from 45 countries around the world, the Open University of Catalonia (UOC) in Spain has a long history in the field of online learning.

What's different about the UOC is not just that the university is $100 \%$ online. It's that the student is at the center of his or her own academic program. This is the main point of this learning model. It moved from the stage where professors were giving lectures to a point where students, mentored by their faculty members, could take the knowledge that they need directly." The UOC's virtual desktop, for example, allows students to navigate at will through tabs that feature planning and scheduling, teacher and classmate communications, a digital library and web resources, and testing and assessment.

\section{The teacher as facilitator of learning}

ICT has many benefits for the classroom teacher. Using presentation software enables teachers to show ideas dynamically (Moseley et al 1999), and deliver content effectively. For example: CD-ROMs make vivid multimedia worlds available and store large amounts of information ... that teachers suddenly have at their fingertips. (McKnight (2002)

Teachers can use a range of teaching tools such as discussion boards, forums, email, raps, web quests, video and 
digital photography, e movies, and even mobile phones as tools for delivery of class program. This opens reciprocal dialogue between members of the class community and may be extended to the school community at large through activities such as blogs and wikis, (Kinzie, 2005, pB01)

Research suggests that incorporating ICT into the English curriculum can improve writing and reading skills, develop speaking and listening skills, support collaboration, creativity, independent learning and reflection (Becta,2003, VTC,2003) (cited in Becta 2005)

\section{The student as an active participant in learning}

ICT can enable students to: access information and respond to a widening range of texts, organize and present information in a variety of forms, broaden the range of audiences for their work, compose a widening range of texts for a broad range of purposes, compose for real audiences. ICT can support them in their choice of genre for audience and purpose, identify key characteristics and features of text and develop understanding of language and critical literacy (Becta, 2006).

\section{The Multimodal text}

Using ICT changes the nature of composing and allows the writing process to become more fluid. Students creating both traditional and multimodal texts using ICT will often attend to the visual and spatial qualities of text creation early in the design process as in selecting fonts, templates or choosing images. (Interactive Education, 2006)

ICT enhances composing in English by allowing students to plan, draft, revise and edit their own and others' writing using a word processor and other desktop publishing packages, use hypermedia to write up, lay out and present their work for publication on the Internet, transform different media into one text and email for a range of communication purposes. In addition, ICT helps students to design websites using informative/ persuasive texts, publish writing in a variety of forms, use video editing programs and programs such as Photo 
Story, Movie maker and animation software packages. This, in turn will enhance students' ability to integrate different media into one text and communicate with a wider group of people in a range of forums (e.g. via e-mail, newsgroups, online conferencing raps) and hence promote collaborative learning.

\section{Responding to ICT Texts}

Words, sentences and texts types. The verbal aspect of communication is only part of what is being communicated in a multi-media text. There is often a tension between the verbal act of meaning-making and the meaning which comes from layout and from other resources intrinsic to the materiality of digital texts (e.g. hyperlinks) (Interactive Education, 2006)

ICT also enhances responding by allowing students to compare the way information is presented in a range of texts; identify and engage with the key characteristics and features of text types; discuss the merits and limitations of particular text types; evaluate the validity, accessibility and relevance of information sources and investigate ways in which reading strategies are adapted to suit different texts.

\section{The 21st Century EFL/ESL Teacher}

Teachers more than ever have a vital role to play in helping students realize their futures by providing them with instruction that gives direction and allows them to hone their new cognitive and technological skills. In a nutshell, (Daggett, 2010) suggests that students need facilitated content to be fully capable citizens, whether its blogging on a social network site or solving a math problem. They may have limitless technology and information at their disposal, but can they access that information efficiently and effectively? Can they evaluate it critically and competently and identify objective facts from propaganda? Do they understand the real ethical, legal, and moral issues concerning access to and use of information? Can they create meaning from data? In essence, do they know the value of information, aside from what is needed to pass a test? When teachers start asking these questions, they begin to look at education in the larger 
context of today's society. That context includes helping students solve real-world current problems and prepare for a future of unknowns.

\section{What Do EFL Teachers Need to Know and Do?}

If we commit to a vision of 21st century knowledge and skills for all students, it is vital that we support EFL teachers in mastering the competencies that ensure positive learning outcomes for students. These include:

- Successfully aligning technologies with content and pedagogy and developing the ability to creatively use technologies to meet specific learning needs.

- Aligning instruction with standards, particularly those standards that embody 21st century knowledge and skills.

- Balancing direct instruction strategically with projectoriented teaching methods.

- Using a range of assessment strategies to evaluate student performance and differentiate instruction (including but not limited to formative, portfolio-based, curriculumembedded and summative).

- Acting as mentors and peer coaches with fellow teachers.

- Designing developmentally appropriate learning opportunities that apply technology-enhanced instructional strategies to support the diverse needs of learners.

- Applying current research on teaching and learning with technology when planning learning environments and experiences.

- Mastering basic hardware and software operations, as well as productivity applications software, a web browser, communications software, presentation software, and management applications.

- Knowing how, and under which conditions, students learn best, and teachers must anticipate and be able to effectively respond to the difficulties students encounter. 
- Thinking Creatively through :

a. Using a wide range of idea creation techniques (such as brainstorming).

b. Creating new and worthwhile ideas (both incremental and radical concepts).

c. Elaborating, refining, analyzing and evaluating their own ideas in order to improve and maximize creative efforts.

- Working Creatively with Others through:

a. Developing, implementing and communicating new ideas to others effectively.

b. Being open and responsive to new and diverse perspectives; incorporating group input and feedback into the work.

c. Demonstrating originality and inventiveness in work and understanding the real world limits to adopting new ideas.

d. Viewing failure as an opportunity to learn; understanding that creativity and innovation is a long-term, cyclical process of small successes and frequent mistakes.

- Implementing Innovations through:

a. Acting on creative ideas to make a tangible and useful contribution to the field of EFL.

b. Going beyond basic mastery of skills and/or curriculum to explore and expand one's own learning and opportunities to gain expertise

c. Demonstrating initiative to advance skill levels towards a professional level.

d. Demonstrating commitment to learning as a lifelong process.

e. Reflecting critically on past experiences in order to inform future progress

\section{Impact of using ICT applications on EFL student achievement}

Over the last few years there have been important calls for new literacies to become an integral part of language education. 
Yet traditional approaches to technology continue to persist in many contexts. Although the role of teachers in this problem has been acknowledged, little is known about how teachers' everyday digital literacy practices influence teaching with technologies. Informed by Literacy Studies, Tour (2016) reports the findings from a larger qualitative study and explores the relationship between technology use in personal and professional domains of three language teachers. She found that the participants' digital mindsets, comprising assumptions about affordances of digital technologies, shaped the ways in which the participants used digital technologies within and beyond classrooms. New literacies required creative and elaborated assumptions about affordances; however, these understandings had different significance for the participants.

The results of empirical research, particularly when considering meta-analyses, give a number of tangible results:

First, that there is solid evidence regarding the effects of technology on cognitive skills development, particularly in areas related to visual-spatial skills and nonverbal forms of intelligence. Second, that there is an intrinsic difficulty when researching the effects of technology on educational performance. In practice, there is no conclusive evidence about the effects of technology upon academic achievement. This is partly for obvious reasons -they are teaching means that can be used with a wide range of methodologies and strategies, for which there is a great deal of empirical research done with inconclusive results - but also because the right methodological approach, which should involve large longitudinal studies, has not been put in place yet. (Center for Educational Research and Innovation, 2008)

In the same vein, Schacter (2017)the meta analysis of 700 empirical studies on technology-based teaching and learning various subjects showed positive gains in achievement on researcher constructed tests ,standardized tests and national tests.

Al Ammary (2012) concluded that Educational Technology (ET) can empower teachers and learners, promote change and 
foster the development of twenty-first century skills. The results show that at the student learning and achievement have been affected when the teaching and learning processes are enhanced by ET. ET has motivated the students to get more involved in learning activities through which they become more active and more interested in learning. Moreover, the academic staff believes that adopting such technologies can enhance their communication with the students, reduce the teaching pressure caused by the course material preparation and make the lecture material available at the time of the discussion. However, the findings demonstrate some impediments facing both the students and instructors in adopting such as the insufficient ICT infrastructure and computing facilities, lack of sufficient technology budget and IT investment, and technical support.

A host of studies (Caena, 2011 ; Otedola, 2012 ; Schacter, 2016; Thouseny \& Bradly, 2011; Tour, 2015, White, 2013) concluded that:

- Students learn basic skills-reading, writing, and arithmetic-better and faster if they have a chance to practice those skills using technology.

- Technology engages students, and as a result they spend more time on basic learning tasks than students who use a more traditional approach.

- Technology offers educators a way to individualize curriculum and customize it to the needs of individual students so all children can achieve their potential.

- Students who have the opportunity to use technology to acquire and organize information show a higher level of comprehension and a greater likelihood of using what they learn later in their lives.

- By giving students access to a broader range of resources and technologies, students can use a variety of communication media to express their ideas more clearly and powerfully.

- Technology can decrease absenteeism, lower dropout rates, and motivate more students to continue on to college. 
- Students who regularly use technology take more pride in their work, have greater confidence in their abilities, and develop higher levels of self-esteem.

\section{References}

Al Ammar, J (2012). Educational Technology: A Way to Enhance Student Achievement at the University of Bahrain. Procedia - Social and Behavioral Sciences 55. 248 - 257 Alsied, Safia M and Pathan, Mustafa M (2013). The Use of Computer Technology in EFL Classroom. International Journal of English Language \& Translation Studies 1, (1). Anderson, N. (2005). "Mindstorms" and "Mindtools" Aren't Happening: digital streaming of students via socioeconomic disadvantage. E. Learning Journal 12, (2).

Australian Council for Educational Research (2013). Digital

Learning Research Teaching and Learning and Leadership.

Barton, G. (2006). ICT in English. Retrieved on April 10th 2016

from www.longman.co.uk/tt-seceng/curric-sup/websites Larticle.htm

Banaszewski, T. (2002). Digital Storytelling finds its place in

the classroom. Multimedia Schools Jan/Feb 2002 Retrieved on April 11th $/ 2006$.

Barnawi, Osman Z (2015) The Internet and EFL College Instruction: A Small-Scale Study of EFL College Teachers' Reactions. Reviewed from www.itdl.org/index.htm

Barton, G. (2006). ICT in English. Retrieved on April 10 th 2016

from www.longman.co.uk/tt-seceng/curric-sup/websites Larticle.htm.

Beach, R., \& Myers, J.(2001). Inquiry-based English instruction: Engaging students in life and literature. New York: Teachers College Press.

Beavis, C. (2006) Lara meets literacy: Computer Games and English. Retrieved on April 11th 2016 from http://www.sofw.eb.vic.edu.aa/english

Becta (2006). Benefits and features of ICT in English. ICT in the Curriculum. Retrieved on April 11th 2006 from http://curriculum.becta.org.uk/docserver.php/?docid=657 
Becta (2006). ICT in the Curriculum. Retrieved on April 11th 2016 from http://curriculum. becta. org.uk/ docserver.php?temid $=255$

Becta (2006). Evidence on the progress of ICT in education. Coventry: Becta

Berk, Martin (ND) Language and Technology: Teaching and Learning Methods for Future Generations. Retrieved on April 7th 2016 from Courseworkspot.co.uk.

Boardman, M. (2005). The language of websites. London: Routledge.

Caena, F (2011). Professional Development of Teachers' Literature review. Directorate-General for Education and Culture. Lifelong learning: policies and lifelong programme School education; Comenius. EUROPEAN COMMISSION.

Chun, D. M. and Plass, J. L., (1997). Research on text comprehension in multimedia environments. Language Learning and Technology 1,1: 60-81. Retrieved on April $4^{\text {th }} 2016$ from http://llt.msu.edu/vollnuml/chun plass/default.html.

Center for Educational Research and Innovation (2008). New

Millennium Learners Initial findings on the effects of digital technologies on school-age learners.

Daggett, Willard R. (2010) Preparing Students for Their Technological Future

CEO, International Center for Leadership in Education

Dandonoli, P. (1989). "The ACTFL Computerized Adaptive

Test of Foreign Language Reading Proficiency." Modern

Technology in Foreign Language Education: Application and Projects. Edited by F. Smith Lincolnwood. IL: National Textbook.

Douglas, Carol A. Chapelle and Dan. (2006). Assessing language through computer technology. Cambridge: Cambridge University Press

Glenn, M (2008). The future of higher education: How technology will shape learning. The Economist Intelligence Unit, New York. 
Hull, G. A., \& Nelson, M. E. (2005). Locating the semiotic power of multimodality written communication. Research in the Teaching of English, 22 (2), pp. 224-261.

Interactive Education (2006), English Subject Designs. Bristol: University of Bristol. http://www.interactiveeducation.ac.uk/english_designs.ht $\mathrm{mI}$

Jonassen, D. H., Howland, J.L., Moore, J.L., \& Marra, R. M. (2003). Learning to solve problems with technology: A constructivist perspective. Upper Saddle River, NJ: Merrill Prentice Hall.

Kasper, L. F. (2000). "New technologies, new literacies: Focus discipline research and ESL learning communities." Language Learning \& Technology, 4 (2). Retrieved on March 31 2016 from http://llt.msu.edu/ 104, (102) kasper/default.html: 109 -128.

Koehler, M. J., Mishra, P., Hershey, K., \& Peruski, L. (2004). With a little help from your students: A new model for faculty development and online course design. Journal of Technology and Teacher Education, 12(1), 25-55

Kristina Robertson (ND). Preparing ELLs to be 21st-Century Learners. Retrieved on April $8^{\text {th }} 2016$ from WWW.Colorincolorado.og

Lankshear, C \& Knobel, M. (2006). New Literacies and the Challenge of Mindsets. Reviewed from http:// www. geocities. com/newliteracies / Chapter 2.pdf

Luce- Kapler, R., \& Dobson, T. (2005, May/June). In search of a story: Reading and writing e-literature. Reading Online, 8(6). Reviewed from http://www.readingonline.org/articles/art index.asp?HRE F=luce-kapler/index.html

McKenzie, J.(2005). Literacy and Semantic Power Plays. The Educational Technology Journal. 14, (5), June 2005.

McKnight, L. (2002) Dancers not Dinosaurs: English teachers in the electronic age EQ Australia Summer 2002.

Moseley, D., Higgins, S., Bramald, R., Hardman, F., Miller, J., Mroz, M., Tse, H. Newton, D., Thompson, I., Williamson, J., Halligan, J., Bramald, S. and Newton, L. (1999) Ways Forward with 
ICT: Effective Pedagogy Using Information and Communications Technology for Literacy and Numeracy in Primary Schools. Newcastle upon Tyne, UK: University of Newcastle upon Tyne and CEM Centre, University of Durham.

Montano, Jean (2015). The 6 Pros \& Cons of Using Technology in Your Classroom. Journal of English Language \& Translation Studies. ISSN: 2308-5460 Retrieved on March $31^{\text {st }} 2016$ from www.eltsjournal.org

NiK Peachy (2015). Technology can sometimes be wasted on English language teaching .Retrieved on March 31 2016 from

http://www.theguardian.com/education/2012/may/15/te chnology-fails-elt

Organization for Economicco- Operation and Development International Conference (2010). "Learning in the 21st Century: Research, Innovation and Policy"

Otedola, M (2012). Improving the Teaching and Learning of English Language Through the Use of Information and Communication Technology: Prospects and Challenges Olumuyiwa Viatonu, Elusakin Titus Kayode, Nijeria.

Parks, S. et al (2003). Crossing boundaries: Multimedia and pedagogical innovation in high school class. Language Learning and Technology, 7(1), 28-45.

Stansfield, C. (1990). "Some Foreign Language Test Development Priorities for the Last Decade of the Twentieth Century." Foreign Language Annals 23, 395401.

The American Association of Colleges of Teacher Education (2010). 21 ${ }^{\text {st }}$ Century Knowledge and skills in Educator Preparation. Pearson.

Tour, E. (2015). Digital mindsets: Teachers' technology use in personal life and teaching. Language Learning \& Technology, 19(3), 124-139.

UNESCO and Microsoft (2011). UNESCO ICT: Teacher Competency Framework. 
White, J (2013) Digital fluency: Skills necessary for learning in the digital age. Australian Council for Educational Research.

Yagelski, R. (2005). Computers, literacy and being: Teaching with technology for a sustainable future. Reviewed from http://www.albany.edu/faculty/rpy95/webtext/

Young, C (ND) "Beliefs About Technology and the Preparation of English Teachers: Beginning the Conversation," Reviewed from http://www .citejournal.org/ vol5/iss3/languagearts/article1.cfm 
